\title{
Seasonal incidence of the mealybug, Phenacoccus solenopsis Tinsley (Hemiptera: Pseudococcidae) on ashwagandha in Raipur (Chhattisgarh)
}

\author{
CHANDRAMANI SAHU*, J. L. GANGULI AND SUNIL JOSHI
}

Department of Entomology, College of Agriculture, Indira Gandhi Agricultural University, RAIPUR (C.G.) INDIA

\section{ARITCLE INFO}

Received : 19.06 .2017

Revised : 09.08.2017

Accepted : 21.08.2017

\section{KEY WORDS :}

Seasonal incidence, Mealybug, Ashwagandha, Meteorological data, Correlation
*Corresponding author:

Email : chandrasahu2111@gmail.com

\begin{abstract}
Studies on the seasonal incidence of mealybug, Phenacoccus solenopsis Tinsley on ashwagandha, Withania somnifera Dunal was carried out for two consecutive years during 2015-16 to 2016-17. The mealybug, P. solenopsis was observed as a major insect pest on ashwagandha. The present investigation revealed that the maximum population of mealybugs was observed during the second fortnight of December with 123.00 mealybugs per ten centimeter apical stem during 2015-16 while in 2016-17 maximum population was noticed during the first fortnight of January with 117.75 mealybugs per ten centimeter apical stem. The correlation analysis of mealybug population to meterological parameters showed that the population was highly significant and negatively correlated with maximum temperature $(-0.562 * *)$ and minimum temperature $(-0.837 * *)$ during $2015-16$ but highly significantly negatively correlated with minimum temperature $(-0.839 * *)$ in $2016-17$.
\end{abstract}

How to view point the article : Sahu, Chandramani, Ganguli, J.L. and Joshi, Sunil (2017). Seasonal incidence of the mealybug, Phenacoccus solenopsis Tinsley (Hemiptera: Pseudococcidae) on ashwagandha in Raipur (Chhattisgarh). Internat. J. Plant Protec., 10(2) : 270-274, DOI : 10.15740/HAS/IJPP/10.2/270-274. 